\title{
REFLECTIONS ON THE ROLE OF THE FRENCH ADMINISTRATIVE JUDGE
}

\author{
MAXTME LETOURNEUR*
}

7 FE FRENCH administrative tribunal, the Conseil d'Etat, has attained just fame as a champion of individual rights. The success of the Conseil d'Etat in restraining governmental abuse of power and in calling the government to account in damages for its unlawful activities is unquestioned. Some doubt has been expressed, however, as to whether this institution which is predicated upon the separation of the private and public spheres of law should continue to exist in a world where modern technological and social developments have erased any clearly identifiable duality.

The critics make two arguments. First, they contend that the State in the twentieth century has fully entered the economic life of society, operating in much the same manner as a private organization; conversely, private organizations have begun managing public affairs and conducting themselves as public powers. Thus there is no longer a clear division of affairs into private and public law, and the separation of the judicial orders may be said to bear no correspondence to the facts of modern life. The maintenance of such an obsolete system creates incessant problems as to the determination of the law to be applied and the tribunal before which to bring a case.

The second argument is historical. The critics point out that the origin of the Conseil d'Etat may be found in the hostility of the French revolutionaries to the judiciary, which hostility led them to forbid the judiciary from disturbing in any way the administrative activities of the government. From this attitude there is said to. have sprung the separation of the legal orders, which might be viewed as an accidental deformation of the principle of separation of powers or even as a lack of fidelity to that principle. The critics maintain that this historical accident, however beneficial it might have been, need not be set up as an immutable cornerstone of French institutions.

The analysis of the critics may well be questioned. The French administrative tribunal is not merely the-result of a fortuitous error based upon fear of the judiciary, but is in fact a manifestation of their recognition of the radical distinction between public and private interest. Sovereignty and property have been the main themes of the work of the revolutionaries. Sovereignty was the ruling idea of public law, and property the basis of private law. The institution of a dual system of law and courts is, then, fundamentally a recognition of the duality which characterizes the liberal state. This rigorous separation

\footnotetext{
* Member, French Conseil d'Etat.
} 
common to all liberal regimes of the nineteenth century, which has long seemed natural to us, was at the time a new idea in Europe; the Middle Ages had in large part confused sovereignty and property, and the theologians had postulated the "common good" as the end of all law.

Thus, in spite of its ancient origins in the Conseil du Roi, of which the Conseil d'Etat has in a sense been the successor, and in spite of its creation by the authoritarian regime of Napoleon, the administrative tribunal has become an essential part of the tradition of the liberal state. In this sense, the Conseil is a very modern institution, whose survival under the various political regimes that France has known in the nineteenth century has resulted from the fact that its fate was tied to the social structure of the country rather than to any particular constitutional form.

Since the Conseil d'Etat is an embodiment of the principles of the liberal state, it might be said that the present crisis in French administrative law is really just an aspect of the present crisis of the liberal state. If there is confusion as to notions such as the public service and the public domain it is because the fundamental distinctions between public and private law, between sovereignty and property, have come to be obscured.

Whether this crisis should lead to the establishment of a unitary system of courts is the question. Two reasons can be urged against unification. First, it may be paradoxical to let the extension of public authority, which has served to create administrative tribunals of a judicial nature in other countries, impel France to move in just the opposite direction. Second, it may be questioned whether a return to a unitary system would necessarily inure to the benefit of private rights. A retreat from the principles of the liberal state, such as the abandonment of the dual system, could only serve to accentuate the dominant position of the sphere of public law. The protection of individual liberty and the rejection of a world constructed in the image of the Leviathan are basic to the liberal regime. The fact that it is no longer possible to trace with clarity the limitations of the sphere of public activities does not mean that an administrative tribunal is now incompetent to achieve these basic objectives, albeit through a somewhat modified system.

Thus it might be suggested that the administrative tribunal may continue to serve a useful function, not by vainly attempting to contain the scope of public power, but rather by perpetuating the fight for freedom in the very interior of the governmental machinery.

The administrative judge does not attempt to refuse the government the means to govern. Though removed from the restrictive ideology of the past, the present "cooperation" of the administrative judge is fully in accord with the twentieth century government which has within its ken such goals as full employment, economic expansion and social progress. Because he has modified his position to accord with the present-day reality of governmental authority, the administrative judge lends a favorable ear to administrative initiative, pre- 
sumes the legality of administrative action, compels litigants to submit first to administrative decision and to seek redress later, refuses to grant injunctions against public officials, and uses with extreme caution his power of temporarily enjoining the enforcement of administrative decisions where no emergency exists. While much freedom is thus granted to the government, it is vital to recognize the rigorous judicial control over the executive which is exercised by the administrative judge.

The legal basis for the control exercised by the Conseil d'Etat has been a favorite topic of discussion in France. Notwithstanding the variety of views that have been advanced, it seems clear that the source of authority is to be found in the principle of separation of the executive and the legislative powers. The Conseil d'Etat operates to conserve the supremacy of law against possible infringement by the executive.

The method by which the administrative tribunal applies the law is twofaceted. First, it is obvious that the exigencies of social life in such areas as the exercise of the police power and the public services imply a rather broad area of discretion. That the Conseil d'Etat recognizes this area of discretion is made clear by reference to one of its own statements: "It is the right of the executive apart from any legislative delegation and in virtue of its inherent powers, to determine which safety measures are to be applied in particular situations." (Labonne, 8 August 1919, Rec. p. 737.) On the other hand, as a counter-balance to the extended powers thus conceded to the government, the administrative judge forcefully reaffirms the supremacy of law; with the single exception of political decisions such as acts concerning the relation of the government and Parliament or diplomatic acts, every administrative decision is always subject to the scrutiny of its compatibility with the law, and this scrutiny will be applied upon the application of any interested party.

The foregoing methods may well constitute an effective and well balanced means of controlling the executive when the Assembly votes clear and relatively detailed laws. However, during the last quarter century there has been a tendency to omit stating the law precisely and instead to resort to laws of general principles or merely to pass enabling laws which allow the government during a limited period of time to change the existing law by means of decree.

In order to prevent such loose legislation from nullifying their role in maintaining the supremacy of law, the administrative judges have held such laws not to exempt the government from respecting the fundamental rules of the legal system, or, as some writers have said, the "body of law," unless the contrary has been expressly and unambiguously stated in the statute.

As to the power given the executive to modify existing law, the position of the judge seems less certain. The solution taken by the courts was to find certain legal principles so fundamental that the government is bound to respect them. An example of such a fundamental principle is the non-retroactivity of 
laws. This theory of general principles is not exclusively court made; the legislature itself has put into a number of laws a reservation upon the power of the executive determined by "the fundamental principles recognized by the laws of the Republic." The theory of general principles, as applied by the court, represents an audacious and enlightened response to a threatened deprivation of power. The following materials regarding the general principles will indicate the way in which the administrative judge adapts to present day political realities and continues to play a meaningful role in the governmental structure.

The general principles are a series of unwritten fundamentals, the violation of which will result in the annulment of an executive act upon the theory of abuse of authority. The Conseil d'Etat takes the position that the reason the general principles have not been explicitly written into law is that their existence is so inherent in the political, social and economic organization of the country that they do not need to be expressly articulated in any statutory text. Nonetheless the question arises as to the sources of these general principles.

The primary sources used by the Conseil d'Etat are the Declaration of the Rights of Man of 1789, and the Preamble to the Constitution of 1946; indeed the Declaration and the Preamble present the ideas, the "program," that the makers of the various French constitutions since the Revolution have tried to actualize. The oldest and most authoritative general principles made important by these two documents are those of liberty and equality.

Some aspects of liberty have, indeed, been written into formal laws. Among these are freedom of the press, freedom of assembly and freedom of religion. But under the broadness of the general principle approach to law, the Conseil has developed other freedoms, such as that of personal freedom of movement. As an example of this freedom, the Conseil has annulled a mayor's order permanently forbidding tubercular persons to live in a particular area.

Similarly, the Conseil has developed the principle of freedom of thought, an example of which may be found in decisions forbidding the removal of any public official from his job because of his ideas or beliefs. Even a principle that has been enacted into law in some limited form may be expanded by the Conseil, as was the freedom of commerce, which, though only briefly mentioned in an act of 1791 , has been given content to the extent of a prohibition against the participation of municipalities in commercial or industrial activities.

A second fundamental principle formulated by the Conseil d'Etat is that of equality. The courts require the equality of all citizens before the law and with respect to all public fees. The equality notion has also been extended to the requirement of admission to public functions and to the demand for equal treatment of people engaged in business activities.

It should be noted that there is no hard and fast rule as to the source of these general principles. They may come from the constitution as did those noted above; they may come from the Civil Code as does the provision regarding non- 
retroactivity of laws mentioned previously; or they may be first articulated by the Conseil itself, as was the rule requiring a fair hearing in every case that is likely to affect a party morally or economically.

A new general principle may be recognized at any time, either fortuitously or intentionally. In the former case, the judge has merely not yet had occasion to deal with the principle. In the second, more interesting, situation the judge wishes either to give expression to his awareness of a change in the realm of ideas or political organization or to prevent from being neglected a rule which has hitherto been incontestable, but for which it has become necessary to articulate express status. An example of this situation can be shown with respect to the right of appeal from every administrative act on the ground of abuse of power. This right of appeal had never been declared a general principle since it had never been questioned. But under the Vichy government, a law of May 23,1943 , declared that arable lands left uncultivated by their owner could be given to a third party and that such grant could not be the subject of an appeal. It was only then, in 1943, that the right of appeal was first promulgated as a general principle. Conversely, a general principle could, apparently, lose its status, though no such situation has yet occurred.

It must be noted that the general principles articulated by the Conseil d'Etat have the force of law, but only the force of law. They are predicated upon the assumption that they represent views which the legislature meant to enact but never expressly put into statutory form. Thus the legislature always has the power to repudiate a principle announced by the Conseil. As a practical matter, once a principle has been announced by the Conseil, it becomes rather difficult for the Assembly to repudiate it; in this sense it has been suggested that the Conseil operates as a keeper of the legislative conscience. Also, as a general matter the Conseil operates not in opposition to the legislature but promulgates general principles to complement the legislative job. The experience with the Vichy government, a temporary government in which laws were drawn up by a single man rather than voted upon by an elected assembly, was extraordinary rather than typical of the relationship of the Conseil to the Assembly. Thus the Conseil, working harmoniously with the Assembly, acts both to check possible excesses by the government and to protect the fundamental freedoms of the citizens, thereby continuing to fulfill a fundamental need of the modern state. 